日薬理誌 $58 ， 430 \sim 436(1962)$

\title{
ATP の生体作用に関する知見補遺
}

第 1 報 白鼠に於ける大脸皮質切片並びに横隔膜の糖質代謝に 及经す ATP の影響

\author{
北 谷 靖 子 \\ （和歌山県立医科大学薬理学教室） \\ （昭和37年 3 月14日受付）
}

ATP が生活細胞内に於ける生物学的力源運搬体として重要な役割を演しててい事実に関しては数多くの知 見があり，その生理学的乃至生化学的意義てついては今更賴言を要しない，而して近時上述の知見を基礎とし て，ATPを治療的に応用せんとする試みがなされ，殊に代謝障碍疾患に対しては認むべき改善効果を举げっつ ある.

処が ATP は健常な細胞膜通過が甚だ困難であるのみならず，通常治療上便用される ATPは僅か 10〜40 $\mathrm{mg}$ 飞過ぎず，今仮に適用 ATP が細胞膜を通過したとしても付与し得る力源は微々たるものであり，従ってこ

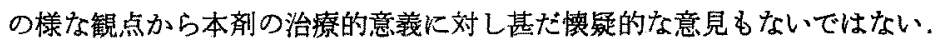

他面村野等1)23) は ATP の生体作用に種々検討を加克た結果, 本㘊の徽量 $(0.5 \sim 5 \mathrm{mg} / \mathrm{kg}$ ) を体外から動 物に適用した場合でも明らかな生体内糖質及び脂酸代謝, 更に燐酸代謝の促進像が招来され，且っ之等の影響は $24^{\mathrm{h}}$ 前後存在するとし，適用 ATP の生物学的能動性を肯定すると共に, 該効果発現は単に本削の血管抾張作

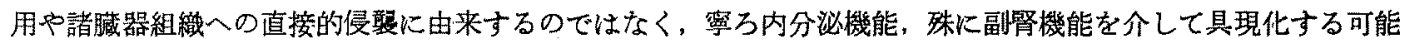
性が甚た濃厚であると述べている，即ち生体に ATP を適用後, 脳並びに骨骼筋細胞内の ATP は明かに增加 しているに拘らず，適用 ATP が直接該細胞内に捕捉せられた形跡はなく密ろ王倒的に副腎に集中している

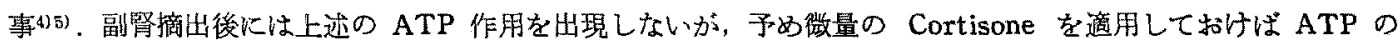
生体作用は美事に再現される事. Alloxan 楉永時 ATP それ自体は殆えど治療的能動性を示さないが, Insulin と併用すれば著しく前者の作用が增強される事等を主張している。

然し乍ら，適用 ATP が如何なる機序で Cortisone, Epinephrine 並びに Insulin の糖代謝効果を增強せ しめ得るのか未だ辛かではなく、面に適用 ATP が上述 Hormone の標的藏器組辀に於ける作用効果を增強せ しぬる如き様相を示している点を考えれば，投与 ATP が缄器組織細胞機能に対し直接的に何等かの影響を与 党る可能性も全く否定出来ない，

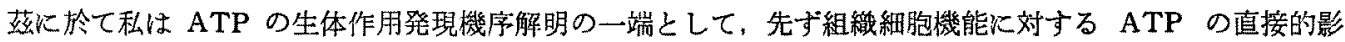
響の有無を検する目的で, ATP 適用下で最も著しい燐酸代謝の変容が招来されるのは大脳皮質と筋細胞であっ

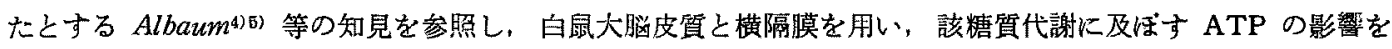
検し, 更に 2,4-Dinitrophenol（DNP）の生体内糖代謝障碍はATP の併用により著しく改善されたとする村野 等1)23) の知見に関しても併せ検討を加えて見たので，その成續を報告する。

\section{実験方法並びに材料}

実験動物としては体重 $120 \mathrm{~g}$ 内外の Wistar 系雄性白䳔を用い，実験使用前少なくとも 2 週間以上オリエン タル固形飼料で飼養した後, 条件に適したものを選别して実験に供した。

先ず白鼠を断頭失血死せしめた後，手早く脳髄並びに横隔膜を露出せしめ, 予め水冷しておいた KrebsRinger 燐酸緩衡液中に切断浸漬した後，大脳皮質切片と適当な大きさになる様に横隔膜を細断した。

叉副腎摘出は定法に従って Ether 麻醉下背部皮腐を切開して両側副腎を露出した後, 鈍的に摘出し, 直ち に開鎖して Penicillin と Cortisone $7.5 \mathrm{mg} / \mathrm{kg}$ を皮下注射した. 而して Cortisone 注射は連日 2 週間施行し， 殆んど摘出処置による侵解が去り順調な経過を涉ったものだけを選び，最終注射 $24^{\mathrm{h}}$ 後の白閶を実験に供した。 
次に被検組織の酸素消費測定はWarburg の検圧装置を用い，充填気体は全酸素とし且組織浮游液はKrebs-

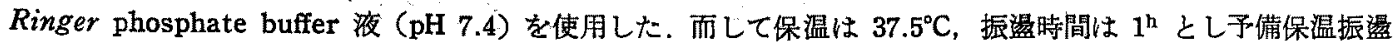
$10^{\mathrm{m}}$ 後に側室から ATP 乃至 DNP を主室に入れ $\mathrm{Qo}_{2}$ に及活す影響を検した. 又各 Vessel 中の浮游液は $2.0 \mathrm{cc}$ とし, 大脳皮質切片は約 $30 \mathrm{mg}$ (新鮮重量)，横隔膜は約 $100 \mathrm{mg}$ に一定し，成續は全て新蘚重量 $1 \mathrm{mg}$ 宛の值 で表示し, 㑡室中の液量は $0.2 \mathrm{cc}$ と定め, 全て最終濃度で示した。な打保温振遗処置後の浮游淮中の glucose 定量は Anthrone 法，乳酸定量は Barker-Summerson の原法6に従って実施した。

実験に用いた ATP は興和化学研觉所に於て特に精製後分与されたDisodium 塩であるが，実験使用前予 め Cohn-Carter の術式》により純度検定を行い.95\%以上のものを選んだ.叉 DNP は和光純薬製のものを本教室 で Sodium 塩とし実験に用いた。な抢その他の試薬は全て市販特級品を用いた。

\section{実 験 成 精}

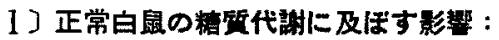

A）大脳皮質切片に於ける実験：

(i) ATP 単独添加の場合:

得られた成蝜は第 1 表に示す通りである. 即ち基質 glucose 存浮游液から取除くと酸素消費量 $\left(\mathrm{QO}_{2}\right.$ ： $\mu 1 / \mathrm{mg} / \mathrm{h}$ ) は0.93土0.225, 乳酸生成量（QL : $\mathrm{r} / \mathrm{mg} / \mathrm{h}$ ) $0.8 \pm 0.41$ 程度に止まったが，基質として glucose (200mg\%) を添加すれば $\mathrm{Qo}_{2}$ は $1.61 \pm 0.398$ と明らかに上㫒し，糖摄取（QG：r $/ \mathrm{mg} / \mathrm{h}$ ) は $13.9 \pm 2.74$ と

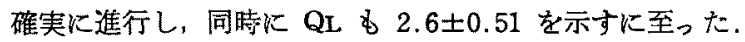

そこで ATP $5 \times 10^{-5} \mathrm{M}$ 乃至 $10^{-4} \mathrm{M}$ を添加して見たところ，軽度乍ら $\mathrm{QO}_{2}$ の低下傾向を示したが，全般的 有意な変化は現われなかった。

(ii) DNP 乃至 $\mathrm{KCl}$ と併用の場合 :

DNP $5 \times 10^{-5} \mathrm{M}$ 単独適用時には第 1 表の如く著しい $\mathrm{QO}_{2}$ の上昇と共に QG と QL の明かな上年が現われ， 叉 $0.1 \mathrm{M} \mathrm{KCl}$ 添加 (カリウム効果) の場合も上述 DNP と本質的に機作を異にするが，同様湆著しい $\mathrm{QO}_{2}, \mathrm{QG}$ 並びに QL の上昇が招来されるに至った。

そこで上述二者に各々 ATP $5 \times 10^{-5} \mathrm{M}$ 乃至 $10^{-4} \mathrm{M}$ を添加して見た，先ず DNP に ATP $5 \times 10^{-5} \mathrm{M}$ を併 用して見たが，DNP 単独適用時に比し軽度の $\mathrm{QO}_{2}$ 低下と $\mathrm{QG}$ の上其傾向を現わすに過ざず，有意な影響は認 め難かった．然し ATP の併用量を 10-4 M に增せば，QG 並びに QL は殆んど差異ないに拘わらず，DNP に よる著しい $\mathrm{QO}_{2}$ の上昇は明か炕剕せられ正常水集に近接する傾向が現われるに至った。

之に反して $\mathrm{KCl}$ と併用時には ATP $5 \times 10^{-5} \mathrm{M}$ 並びに $10^{-4} \mathrm{M}$ 添加群共, $\mathrm{KCl}$ 単独效果流し些の抑制乃 至增強作用も現わさなかった。

B）横隔㸟に於ける実験 :

(i) ATP 単独添加の場合 :

横隔膜は大脳皮質切片と趣を巽にし，glucose 基質の有無に殆んど影響されず，両者間の $\mathrm{QO}_{2} ， \mathrm{QG}$ 並びた QL は殆んど差異は認められなかった。

そこで ATP $5 \times 10^{-5} \mathrm{M}$ 乃至 $10^{-4} \mathrm{M}$ を各々単独で添加したが，該糖代謝に対し有意な影響を与えなかった。

(ii) DNP と併用の場合:

横隔膜に DNP を添加すれば大腷皮質の場合を同様 $\mathrm{QQ}_{2}$ の上年を現わすが，糖提取並びに乳酸生成状況に

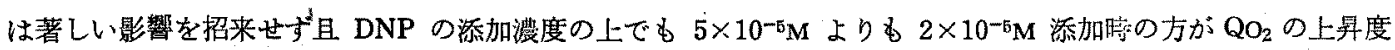
は大であった．但し後述する樣に ATP 注射群並び飞副腎摘出群に於ける DNP 添加の影響は寧る DNP $5 \times$

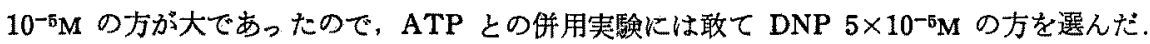

即古 DNP $5 \times 10^{-5} \mathrm{M}$ と ATP $5 \times 10^{-5} \mathrm{M}$ 乃至 ATP $10^{-4} \mathrm{M}$ 併用すれば統計的には有意ではないが， $\mathrm{QQ}_{2}$ の低下換言すれば正常水準への近接傾向が窺われた，但し QG 並びに QL 值の上では認さべき変化は招来され なかった。 

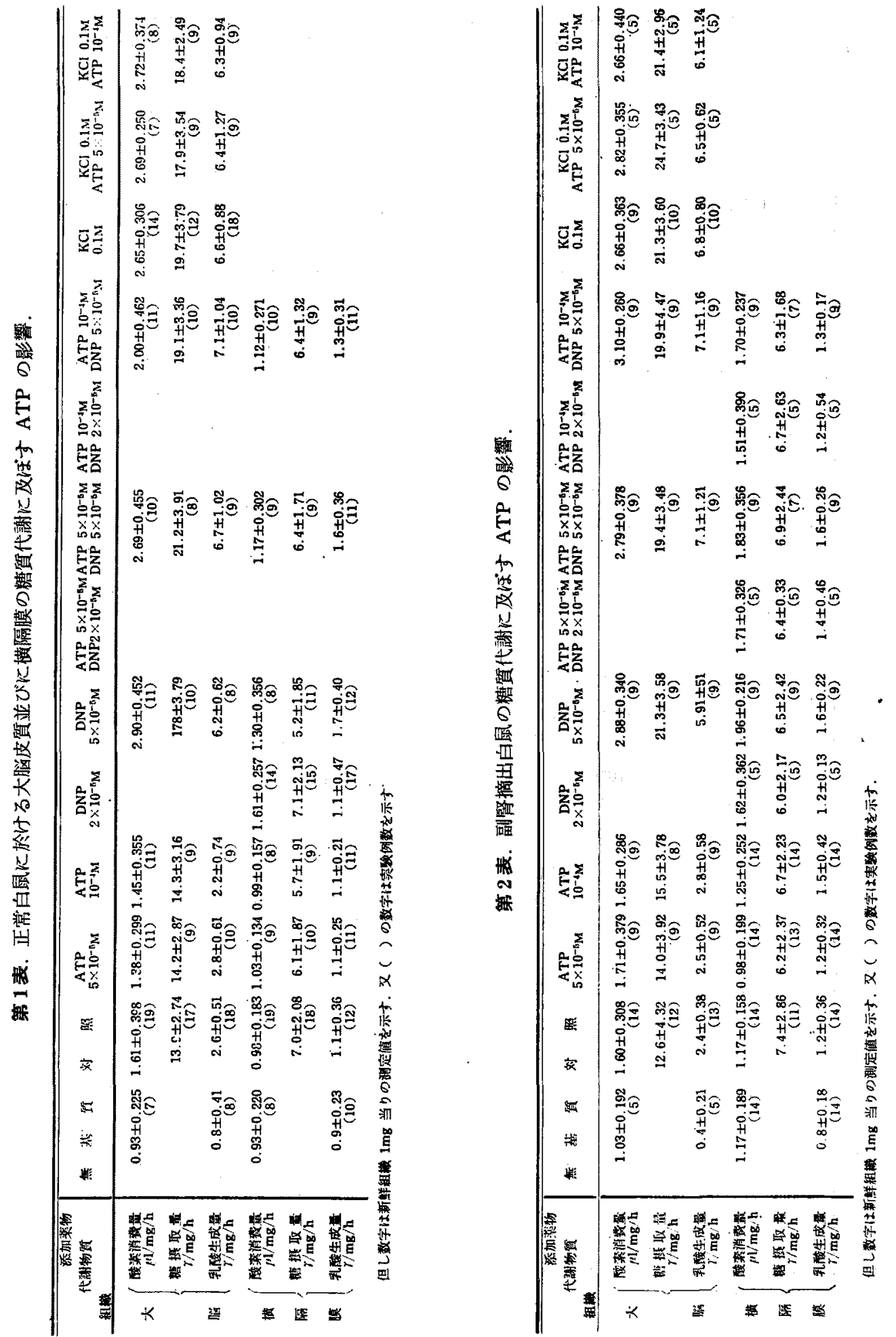


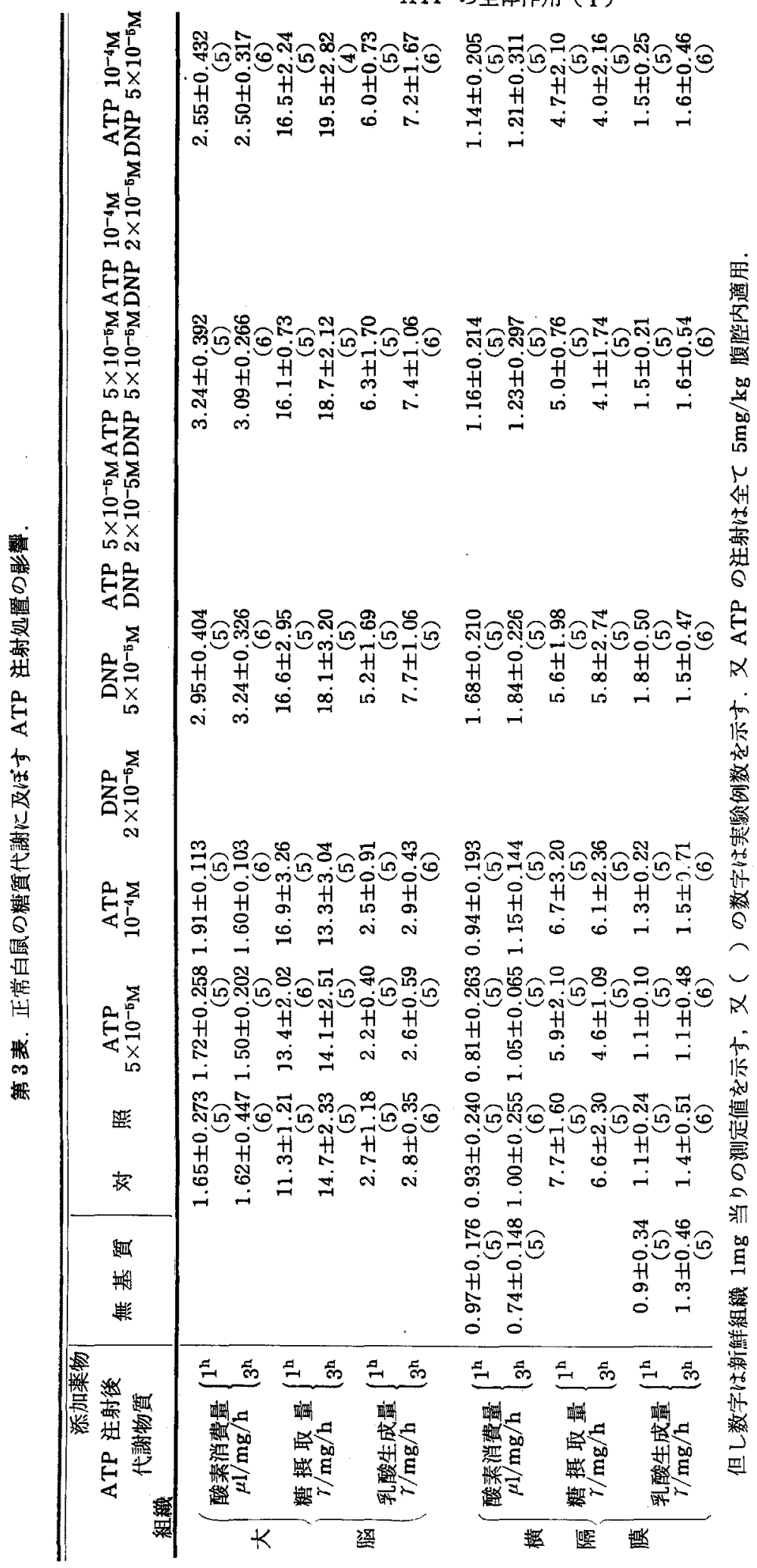




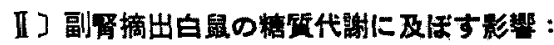

村野等1ー8）の記載依れば，DNP 乃至 ATP はその作用機序を翼にするが，斉しく正常白鼠に適用した場 合著明な糖代謝の昂進を招来させるが，副腎摘出白鼠では該昂進像は台頭せず，反，て抑制傾问すら認められる と云われ，父正常白鼠に於て ATP の同時併用はDNP に上る昂進效果を著しく緩解せしめると云われる. 茹 に於て私は副腎摘出白鼠につき検討を加えて見た。

A) 大脳皮質切片に於ける実験：

(i) ATP 単独添加の場合 :

得られた成績は第 2 表に示す如くであった．即ち副腎摘出白鼠に於ける $Q Q_{2}, Q G ， Q L$ は 3 者共正常群の場 合と殆んど差異は認められなかった，そこで ATP $5 \times 10^{-5} \mathrm{M}$ 乃至 $10^{-4} \mathrm{M}$ を各々添加して見たところ，有意で

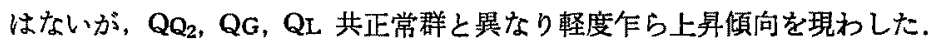

(ii) DNP 乃至 $\mathrm{KCl}$ と併用の場合 :

DNP 乃至 $\mathrm{KCl}$ 添加後発現する作用像は質的にも量的にも正常群の場合と殆儿ど差異は認められなかった。

そこで ATP との併用を試みた，即ち DNP と ATP $5 \times 10^{-5}$ M との併用は DNP 単独時に比乙有意な変 化を招来させなかったが，ATP $10^{-4} \mathrm{M}$ 併用群です正常群に於て出現した DNP Kよる Q $Q_{2}$ の上年を㧕制する 傾向は些む認め得なかった。他面 KCI との併用時に於てる ATP の併用影響は出現しなかった。

B）横隔膜に於ける実験：

(i) ATP 単独添加の場合 :

副腎摘出に伴ら横隔膜の糖代謝変容は認められなかった。. 叉 ATP $5 \times 10^{-5} \mathrm{M}$ 乃至 $10^{-4} \mathrm{M}$ 添加時にも著変 は見出し得なかった。

(ii) DNP 之併用の場合:

正常白鼠の横隔膜では DNP 適用に伴う $\mathrm{QQ}_{2}$ の上年度は $5 \times 10^{-5} \mathrm{M}$ 添加時よりも $2 \times 10^{-5} \mathrm{M}$ の方が大で あったが，副腎摘出の際では寧ろ $5 \times 10^{-5} \mathrm{M}$ の方が大であり，DNP に対する感受性の変調傾向を予想せしめ た.

そこで先ず DNP $5 \times 10^{-5} \mathrm{M}$ と ATP の併用を行って見ると，正常群では ATP $5 \times 10^{-5} \mathrm{M}$ 乃至 $10^{-4} \mathrm{M}$ 共 程度の差こそあれ，DNP 添加による $\mathrm{QO}_{2}$ の上㫒は軽度乍ら育しく抑制せられたが，本群に於ては大脳皮質の 場合之同様 ATP $5 \times 10^{-5} \mathrm{M}$ 乃至 $10^{-4} \mathrm{M}$ 併用時には有意な抑制像は出現しなかった。 叉 $\mathrm{DNP}$ 適用を $2 \times 10^{-5} \mathrm{M}$ とした場合です ATP $10^{-4} \mathrm{M}$ 併用時には抑制効果は全く影をひそふた．即ち副腎摘出白鼠に於ては DNP に対 する感受性の变調傾向台頭を思わしめるが，依然質的に相似た $\mathrm{QO}_{2}$ の昂進像が出現するのに反し，ATP は正 常群と異なり前者に対する抑制能を殆んど示さなかった。

\section{III 正常白鼠の糖诈代謝に及ぼす ATP 注射処置の影響 :}

前項迄の成績から，ATP を大脳皮質切片乃至横隔膜に適用しても該糖代謝に対し能動的態度を示さない が，DNP 適用に伴う著しい $\mathrm{QO}_{2}$ の上昇に対しては寧ら抑制的に働く反面，カリウム効果に伴う $\mathrm{QO}_{2}$ の上昇に は何等の影響を与兄ない事，他面副腎摘出白鼠に於ては DNP 作用に対する抑制効果は全く消失する事実を知 った。

そこで ATPを予め生体に適用し，爾後作製した大脳皮質切片並びに横隔膜につき検討を加党て見た．なお ATP の適用は村野等の記載に準し全て $5 \mathrm{mg} / \mathrm{kg}$ 腹胿内に注射し, 爾後 $1^{\mathrm{h}}$ 並びに $3^{\mathrm{h}}$ 経過した白鼠を使用し た.

A）大脳皮片に於㤃実験：

(i) ATP 単独添加の場合 :

得られた結果は第3表の如くである。即ち ATP 注射 $1^{\mathrm{h}}$ 後乃至 $3^{\mathrm{h}}$ 後でも，それ自体 $\mathrm{QO}$ ， QG，QL 3 者正常対照群と差買はなく，従って ATP 注射に伴ら直接的影響は外観的炕認められなかった，然し乍ら本 標本に ATP $5 \times 10^{-5} \mathrm{M}$ 乃至 $10^{-4} \mathrm{M}$ を添加して見ると，本剤注射後 $1^{\mathrm{h}}$ 群では正常対照群に於ける場合やや抑 制傾向があったに比し明かな $\mathrm{QO}_{2} ， \mathrm{QG}$ の上䄯を示し，殊に $10^{-4} \mathrm{M}$ 添加時にはその程度が大であった。而して 
注射後 $3^{\mathrm{h}}$ 群に於ては最早上速の㥞な促進像は認められなくなったが，正常対照群に於ける如き抑制傾向は些も 㒛め得なかった。

(ii) DNP と併用した場合 :

DNP $5 \times 10^{-5} \mathrm{M}$ 添加すれば正常群に見られると同様な著しい糖代謝の促進像が現われたが，注射 $1^{\text {方 }}$ 後よ りる $3^{\text {h }}$ 後の方がややその程度が大であった.

そこで ATP との併用添加を施行して見たところ, 注射後 $1^{\mathrm{h}}$ 群に於て ATP $10^{-4} \mathrm{M}$ 併用時, DNP 単独 適用群に比しやや抑制の傾向を現わしたが，注射後 $3^{\mathrm{h}}$ 群では本抑制は一段と明かとなった，但し ATP $5 \times$ $10^{-5} \mathbf{M}$ 併用時は両群共抑制傾向は明確ではなかった。

B）横隔膜に於ける実驗 :

(i) ATP 単独添加の場合 :

ATP 注射群の糖代謝像は正常対照群と比較し特記すべき変化は現われなかった。 叉 ATP $5 \times 10^{-5} \mathrm{M}$ 乃至 $10^{-4} \mathrm{M}$ を添加しても大脳皮質に於ける如き $\mathrm{QO}_{2}$ の上戒像は認められなかった。

(ii) DNP と併用した場合 :

本処置群に DNP $5 \times 10^{-6} \mathrm{M}$ を添加すれば, 副腎摘出群程顕著ではないが, 正常群に比し $\mathrm{QO}_{2}$ の上昇度は 大で, 殆に注射 $3^{\text {h }}$ 後でその感が深かった.

次に DNP $5 \times 10^{-5} \mathrm{M}$ とATP $5 \times 10^{-5} \mathrm{M}$ 乃至 $10^{-4} \mathrm{M}$ との併用を試みて見た。即ち ATP 注射後 $1^{\mathrm{h}}$ 乃至 $3^{\mathrm{h}}$ 両 群共 DNP による $\mathrm{QO}_{2}$ の上界は略々完全に阻止され，殆ん亡゙対照水準に近接する值が得られた。

\section{総括並びに考按}

白氮大脳皮質並びに横隔膜の糖代謝に対し ATP は in vitro で添加してす，僅かな抑制傾向を示すか乃至 殆んど能動性を示さず，叉生体に直接適用した際，更に ATP の添加を行えば寧ろ $\mathrm{QO}_{2}$ の上年を来たしはした が，全般的に云って顕著な影響を与えなかった，処か゚ oxidative Phosphorylation を特異的に阻害する DNP の適用8によって薏起される著しい $\mathrm{QO}_{2}$ の上身に対して添加ATP は抑制的に働らき，殊に横隔膜に於て ATP 注射処置はそれ自体 DNP の反応性を上犁せしめる傾向を現わすに拘らず，低然として添加 ATPは DNP による該上年を抑制し，寧ろその程度は大脳皮質の場合に比し遥かに顕著であり，殆えど完全に抑圧する が決して対照水準以下に低下させる事はなかった. 之に反し副腎摘出白鼠沉於て添加 ATP は些も上述の如き DNP の昂進作用を抑制しなかった．但し DNP とはその作用機序を全く異にし，本質的に大脳皮質の糖代謝を 賦活促進する所謂カリウム効果に対し ATP は些の阻止的態度も現わさなかった。

他面村野等1)-3) は DNP 並びに ATP の生体作用発現機作㰸討を加光, 前者の生体作用は in vitro と 異なり単に酸化的橉酸代謝阻害に由来するのではなく, 副腎系内分泌 (Epinephrine, 糖質コルチコイド) 機能 に薬物的侵龔を与える事が主因であるとし，叉 ATP も同内分泌機能に能働的に動らくばかりでなく，Insulin 効果に対しても顕著な賦活を与兄る事実を各内分泌機能の欠落実験乃至再補充実験で立証し，恐らく ATP の 生体作用発現す各種臓器組織への直接作用のみによるのではなく, 上述内分泌機能を介して惹起せしめるのでは

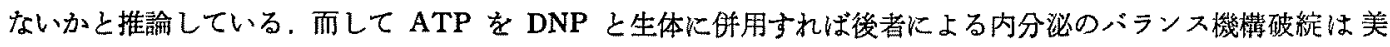

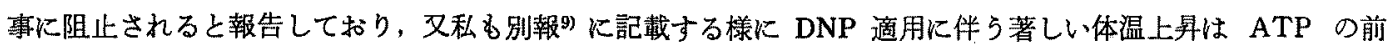
妈置により阻止し得る事を知った。

然らば ATP は直接的に生体細胞汶し真に薬理学的無為であらうか. 又上述の如き ATP の諸 Hormone 賦活効果だけで本剮の生体作用発現を矛盾なく説明し得るであろらか.

少なく共私の得た上述の実験成績を勘案すれば，ATP は正常の両組織の糖代謝には本質的影響を与えず且 つ実駼は全て in vitro で施行されている以上，作用の昜は細胞自体であり生体内の他機能を介する二次的影響

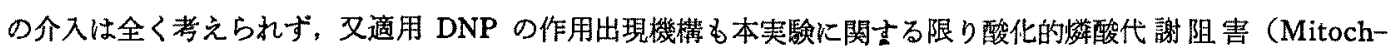
ondria に於て) と考えられる従。て正常両組織の aerobic glycolysis 過程中 DNP による界進に対しATP は抑制的に働らき，本機㭗乃至本因子は ATP の生体注射により明かな影響を受け且副腎摘出により脱落する 
ものであり，本因子も亦当然被検細胞中に存在する管である。

他面 DNP の作用出現能は ATP の生体注射により些む抑制されず，本抑制像は添加 ATPにより初めて

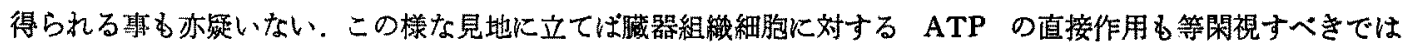
ない様に思われる，事実岩崎（耕）10はAvacan の腸管壁通過を ATP が著しく增強する事寒を報じ，本現 象は ATP の腸管粘膜細胞への直接作用である可能性が藅た源厚であると述べている. 又 DNP 発熱を ATP が阻止する事柄に就ても生体の熱発生部位としての筋細胞の意義は进だ重要であり，DNP の筋稩胞内への透 過難は充分認めるとしても，ATP の該阻止機序に笳細胞に対する直接作用も一部介在しているのではないかと 云う推量も決して早計とは云い難い，殊に私の得た結果で横隔膜に於て ATP が DNP 效果を略々完全に阻止し た事実は上述の現象之相通ずるものがある様に思われ，又脳租織に於ても相似た拮抗像を認め得た点は更にDNP 発熱阻止機序につき将来の手がかりとなるのではあるまいか. 但し茲に注意すべき事は横隔膜細胞と骨骼筋細 胞とは生化学的にも生理学的にも相当大きな相違があり，本事実を以て直ち䈃細胞全般を推諭し得ない事であ る.

更に如何なる機序で DNP の糖代謝昂進に ATP が抑制的に働らくのかに関しては現段階では何等明確な

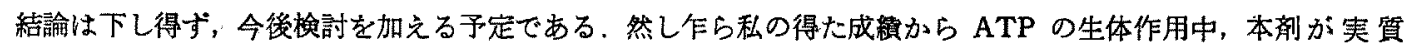
澸器組織細胞へ直接的に影響する可能性は全面的に否定し得ない様に思われる.

\section{結論}

1. ATP は白鼠大脳皮質切片並びに横隔膜の糖代謝に対し有意な影響を与えない。

2. ATP は大腷皮質切片に於けるDNP の䌅代謝昂進に対し抑制的に働らくが，カリウム効果に対しては 有意な影響を与えない。他面 ATP 注射前処㯰群の切片でも同様効果を認め得るが, 副監摘出群では ATP の 該效果は現われない。

3. 横隔膜に於ては ATP の上述新果は一段と顕著である.

4. ATP の生体作用発現機序に関し考察を加兊た。

稿を終るに臨み，御指導及び御校閲を睗った恩師村野医教授に深謝の意を表します。

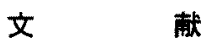

1) T. Murano et al : Osaka City Med. J. 6, 117 (1960).

2) T. Murano et al : 同誌 6, 129 (1960).

3）村野匡外 2 名：日薬理誌 56, 1036 (1960).

4) H. G. Albaum et al : Proc. Soc. Exp. Biol. \& Med. 82, 337 (1953).

5) H...G. Albaum et a1 : 同誌 84, 529 (1953).

6) S. B. Barker \& W. H. Summerson : J. biol. chem. 138, 535 (1954).

7) W. E. Cohn \& C. E. Carter : J. Am. Chem. Soc. 72, 4273 (1950).

8) W. F. Loomis et al : J. biol. chem. 173, 807 (1948).

9) 北谷靖子: 日薬理誌揭载予定.

10）岩崎耕三：日薬理死 56, 224 (1960). 